\title{
足関節果部骨折手術治療成績の検討
}

\author{
公立玉名中央病院整形外科 \\ 宮 䄇一 樹 -中野 哲 雄 \\ 西 壽 二・西川 英 夫 \\ 工 藤 智 志
}

\section{Review of Postoperative Prognosis of Ankle Fractures}

by

Kazuki Miyazono, Tetsuo Nakano, Juji Nishi, Hideo Nishikawa and Satoshi Kudo

Department of Orthopaedic Surgery, Tamana Central Hospital in Kumanoto

We reviewed the prognosis of 66 ankle fractures. Patients ages ranged from 12 to 76 years with an average of 45 years. The prognostic factors were evaluated in these cases. It was found that the type and the stage of Lauge-Hansen's classification, etiology of the injury, degree of reduction, age of patient, presence or absence of compression deformity and other injuries were related factors. Evaluation of these factors would enable us to estimate to some degree the clinical result.

\section{は じめに}

足関節果部骨折の治療には, 解剖学的整復と早期よ りの可動域訓練が必要であり, 手術療法の適応となる 症例が多い. しかし観血的整復固定を施行しても, 不 安定性や荷重面の不適合を残すことがあり治療成績の 悪い症例も存在する.

これまでに足関節果部骨折の治療成績を左右する因 子として, 骨折型, 整復度, 受傷原因, 年令, 合併症 の有無等が挙げられているが, これらの因子と当院に おいて手術療法を行なった症例の治療成績との関連を 調查・検討した.

\section{対象および方法}

症例 : 1982 年から 1991 年の 10 年間に当院で手術 療法を行なった足関節果部骨折は, 64 例 66 関節であっ た。このうち調查可能であった 53 例 54 関節について 検討した. 手術時年齢は 12 歳から 76 歳, 平均 45 歳 であった.
骨折型の分類 : 分類は Lauge-Hansen ${ }^{7)}$ に従った. それによると SA 型 4 関節（ 7 \%)，SE 型 23 関節 (43\%), PA 型 12 関節 (22\%), PE 型 11 関節 (20

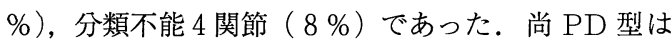
今回の調查検討より除外した（表 1 ).

評価法: X線学的評価は, Burwell 及び Cedell の $\mathrm{X}$ 線像評価基準をもとに浅田らが作成した評価基準 ${ }^{11}$ を用いた。自覚的・他覚的評価は Burwell の評価

$$
\text { 表 } 1 \text { 症例 }
$$

手術症例数 : 64 例 66 関節（1982 年 1 月 1991年 12 月） 調査・検査した症例数 : 53 例 54 関節 分類（Lauge-Hansenの分類）

\begin{tabular}{c|c|c|c|c}
\hline \hline $\begin{array}{c}\text { stage } \\
\text { type }\end{array}$ & I & II & III & I \\
\hline $\mathrm{SA}$ & 2 & 2 & \multicolumn{2}{|}{} \\
\hline $\mathrm{SE}$ & 1 & 8 & 3 & 11 \\
\hline $\mathrm{PA}$ & \multirow{2}{*}{8} & 1 & 3 & \\
\cline { 3 - 5 } $\mathrm{PE}$ & 8 & & 5 & 6 \\
\hline 他 & 4 & \multicolumn{3}{|l}{} \\
\hline
\end{tabular}


法少を用いた。

これらの症例の臨床的評価と治療成績を左右すると 思われる因子との関連を検討した.

\section{結果}

全体の臨床成績は Good35 関節（64\%）Fair15 関 節 (28\%) Poor 4 関節（ $8 \%$ ）であった.

(1)骨折型と臨床成績

SE 型, PA 型, PE 型で stage が進むと治療成績 不良例の割合が増加していた（表 2 ）。

(2)骨折型と術後 X 線評価

$\mathrm{PE}$ 型，分類不能例に anatomical reduction $の$ できない症例があった。また術直後には， anatomical reduction が得られたものの経過中に転位を生じ 結果的に poor reduction となったものが 2 関節あっ た. 1 関節は $\mathrm{SE}-\mathrm{I}$ 型の外果粉砕骨折例， 1 関節は PAー II 型で腓骨骨折放置例であった．表中（）で 示した (表 3 ).

(3)術後 X線評価と臨床成績

anatomical reduction が得られたものの臨床成 績が Poor のものが 4 関節あった。 1 関節は SE－IV 型で内科・精神科的合併症を持つ症例， 1 関節は SE$\mathrm{IV}$ 型で後果の下法転位の残った症例であった。他の 2 関節は前術した症例であった（表 4 ）.

表 2 骨折型と臨床成績

\begin{tabular}{r|c|c|c}
\hline \multicolumn{1}{c|}{$\begin{array}{c}\text { 臨床成績 } \\
\text { 骨折型 }\end{array}$} & Good & Fair & Poor \\
\hline S A - I & 1 & 1 & \\
\hline II & 2 & & \\
\hline S E-I & 1 & & \\
\hline II & 7 & 1 & \\
\hline II & 3 & & \\
\hline P - I & 7 & 3 & 3 \\
\hline II & 1 & 1 & \\
\hline P A - III & 1 & 1 & 1 \\
\hline P E - III & 3 & 2 & \\
\hline IV & 2 & 4 & \\
\hline 分類不能 & 2 & 2 & \\
\hline total & 35 & 15 & 4 \\
\hline$\%$ & 64 & 28 & 8 \\
\hline
\end{tabular}

(4)受傷時年齢と臨床成績

受傷時年齢を 19 歳以下, 20 歳〜 59 歳, 60 歳以上 の 3 群に分けると, 60 歳以上で Fair · Poor の割合 が多かった（表 5 ).

表 3 骨折型と術後 X線評価

\begin{tabular}{r|c|c|c}
\hline $\begin{array}{c}\text { X 線評価 } \\
\text { 骨折型 }\end{array}$ & Anatomical & Fair & Poor \\
\hline S A - I & 2 & & \\
\hline II & 2 & & \\
\hline S E - I & 1 & & \\
\hline II & 8 & & \\
\hline III & 3 & & $(1)$ \\
\hline IV & 11 & & \\
\hline P - I & 8 & & \\
\hline II & 1 & & $(1)$ \\
\hline P A - II & 3 & & \\
\hline P E - II & 4 & 1 & \\
\hline IV & 4 & 1 & \\
\hline 分類不能 & 3 & 1 & \\
\hline
\end{tabular}

表 4 整復度（術後X 線評価）と臨床成績

\begin{tabular}{c|c|c|c}
\hline \hline $\begin{array}{c}\text { 臨床成績 } \\
\text { X線評価 }\end{array}$ & Good & Fair & Poor \\
\hline Anatomical & 35 & 11 & $4(2)$ \\
\hline Fair & & 3 & \\
\hline Poor & & 1 & $(2)$ \\
\hline
\end{tabular}

表 5 年令と臨床成績

\begin{tabular}{c|c|c|c|c}
\hline \hline $\begin{array}{c}\text { 臨床成績 } \\
\text { 年令 }\end{array}$ & Good & Fair & Poor & 計 \\
\hline$\sim 19$ & 11 & & & 11 \\
\hline $20 \sim 59$ & 18 & 10 & 2 & 30 \\
\hline $60 \sim$ & 6 & 5 & 2 & 13 \\
\hline
\end{tabular}

表 6 受傷原因と臨床成績

\begin{tabular}{l|c|c|c|c}
\hline \hline $\begin{array}{l}\text { 臨床成績 } \\
\text { 受傷原因 }\end{array}$ & Good & Fair & Poor & 計 \\
\hline 交通事故 & 12 & 7 & 1 & 20 \\
\hline 転 倒 & 9 & 1 & 1 & 11 \\
\hline 労 災 & 2 & 5 & 2 & 9 \\
\hline スポーツ & 9 & 2 & & 11 \\
\hline 転 落 & 3 & & & 3 \\
\hline
\end{tabular}


表 7 合併症の有無と臨床成績

\begin{tabular}{|c|c|c|c|c|}
\hline \multicolumn{2}{|c|}{$\begin{array}{l}\text { 臨床成績 } \\
\text { 合併症の有無 }\end{array}$} & Good & Fair & Poor \\
\hline \multirow{2}{*}{ 合併症 $\oplus$} & \multirow{2}{*}{\begin{tabular}{|c|} 
精神的既往歴 \\
他部外傷
\end{tabular}} & 1 & & 2 \\
\hline & & 6 & 5 & 1 \\
\hline \multicolumn{2}{|c|}{ 合 併 症 $\ominus$} & 28 & 10 & 1 \\
\hline
\end{tabular}

\section{(5)受傷原因と臨床成績}

転倒・スポーツによるものは治療成績がよかったが, 労災事故によるものは治療成績が悪かった（表 6 ）.

(6)合併症の有無と臨床成績

後療法において悪影響を及ぼすと思われる精神的既 往症や他部外傷のある症例とない症例とを比較すると， 合併症のある症例の臨床成績は明らかに劣っていた (表 7 ).

\section{考察}

足関節果部骨折の治療成績を左右する因子として, 骨折型と stage があるが, Gregory ら ${ }^{5)}$ は PE 型の 高度損傷例に，吉田ら ${ }^{12)}$ は SE-IV型に成績不良例を 多く認めたと報告している，我々の症例では SA 型以 外 stage が進行するにつれて成績不良例が多くなる 傾向にあった。

受傷時年齢については, 小倉ら ${ }^{9)}$ が高齢者ほど予後 がよくないと報告しているが，我々の症例でも同様の 傾向にあった。

受傷原因については，石井ら ${ }^{6)}$ が交通事故によるも のが子後がやや不良であると報告しているが，我々の 症例では労災事故に治療成績のよくないものが多かっ た.

さて，最も治療成績に影響を及ぼすであろうと考え られるものは整復度（術後 X 線評価）であるが, Ramsay ら ${ }^{10)}$ は距骨が $1 \mathrm{~mm}$ 外側に偏位すると距腿 関節面の接触面が $42 \%$ 減少，応力が大きくなり変形 性足関節症への引金になると報告し, Burwell ${ }^{2)}$ は整 復不良例の全例に変形性関節症を認めたと報告し, 整 復の重要性を強調している．諸家の報告でも術後 X 線 評価と臨床成績は一致しているようである。一方，予 後はX線像から想定されるものよりも良好である ${ }^{6)}$ と の意見もある．我々の症例では，前述した 4 関節を除 くと整復度と臨床成績はほぼ一致していた。

整復については, Yablon ら ${ }^{11)}$ が stabilizer とし
ての腓骨の重要を述べ, Mitchell ら ${ }^{8)}$ は腓骨の短縮 が予後に重大な影響を及ほしたと報告し，現在とりわ け腓骨整復の重要性が指摘されている，我々が現在行 なっている腓骨の内固定方法は, 短縮・回旋に留意し, SE 型の斜骨折には螺子 $2 \sim 3$ 本を用いて固定し, $\mathrm{PE} \cdot \mathrm{PA}$ 型の多くは plate 固定をしている. SA 型 の片骨の小さなものには tension band wiring を, 転位の小さい高位の腓骨骨折には Kirchner 鋼線の髄 内固定を用いることもある. しかし喵遖内固定の症例に て臨床成績に影響はなかったものの腓骨の変形を生じ た症例もあり，整復位の保持という点で髄内固定には やや問題があるようである．また，第 3 骨折を伴った 骨片の圧縮変形を伴っているような場合, plateを細 エし plate に合わせるように整復固定しなければなら ないことがあるが, $1 / 3$ 円 plateを腓骨の湾曲に沿っ て曲げることはなかなか困難で，軽度の変形をきたす ことがある

その他，治療成績に影響を与える因子として合併症 があるが，他の骨折や臟器損傷を合併したものは，外 力の大きさと同時に果部骨折の治療に制限があった為 と思われる．また精神的既往症のある場合，特に後療 法に悪影響がある。

$$
\text { ま と め }
$$

(1)手術療法を行った足関節果部骨折 54 関節の治療 成績を検討した。

(2)全体の臨床成績は, Good 64\%, Fair 28\%, Poor 8 \%であった。

(3)治療成績を左右する因子につき調査・㭘査したが， 整復度（術後 $\mathrm{X}$ 線評価）と治療成績はほぼ一致した。

(4)腓骨・外果の整復固定法について述べた.

\section{参 考 文 献}

1）浅田完爾：足関節果部骨折の手術療法. 整形外科 MOOK, 43 : 162-176, 1986.

2) Burwell, H.N., et al.: The treatment of displaced fractures at the ankle by rigid internal fixation and early joint movement. J.Bone and Joint Surg., 47-B : 634-660, 1965

3) Cedell, C.A.: Supination-outward rotation injuries of the ankle. Acta Orthopaedica Scandinavica Supplementum : 110, 1967.

4）藤巻悦夫 : 足関節果部骨折観血的療法の生体力学的検 討と治療成績．整形外科 MOOK, $43: 136-161 ， 1986$. 
5) Gregory, J., Michael, J.P. and Harvey, J.P.: Precise evaluation of the reduction of severe ankle fractures. J.Bone and Joint Surg., 56-A : 979-993, 1974.

6) 石井良章 : 果部骨折の予後. 整形外科 $\mathrm{MOOK}, 43$ : 177-180, 1986.

7) Laug-Hansen, N.: Fractures of the ankle. Arch. Surg., 64 : 488-500, 1952.

8) Mitchell, W.G., et al.: Mandatory open reduction. Its role in displaced ankle fractures. J.Trauma., 19 : 602-615, 1975.
9）小倉 丘, 他 : 足関節果部骨折の治療経験. 骨折, 4 : 131-136, 1982.

10) Ramsay, P.L., et al.: Changes in tibiotalar area of contact caused by lateral talar shift. J.Bone and Joint Surg., 58-A : 356-357, 1976.

11) Yablon, I.G. et al.: The key role of the lateral malleolus in displaced fractures of the ankle. J.Bone and Joint Surg., 59-A : 169-173, 1977.

12）吉田孝太郎：フックプレートを用いた足関節周辺骨折 の治療成績. 整形外科 MOOK, $43: 121-135,1986$. 